\title{
SELVFED GENRESAMPLING ELLER REFLEKSIV SAMTIDSLITTERATUR? FIKTIONALISERING AF SELV OG SAMTID I WEIHUIS SHANGHAI BABY
}

\section{SELF-SATISFIED GENRE-SAMPLING OR REFLECTIVE CONTEMPORARY LITERA-}

TURE | This article applies the concept of 'fictionality' to Chinese Weihui's self-fashioning in relation to her international bestseller Shanghai Baby (1999). Shanghai Baby is a novel that plays on the author's own biography yet at the same time many parts of the narrative are clearly fictionalized. The article argues that Weihui's self-fashioning in the novel and in the me-

dia is part of an international tendency in contemporary literature, a tendency towards using fictionality as a means to reinstall literature and the book as a medium in the global media ontology. Fictionality is here understood not as generic, but as a rhetoric strategy that can be deployed in any kind of communication as an intentional mediation of reality. Shanghai Baby is in many ways a popular multimedia phenomenon that instantly made Weihui a celebrity and spawned a number of internet-based rip offs. But it is also an example of how to understand fictionality in contemporary culture in the context of a highly hybrid, mediatized and globalized age.

KEYWORDS | Contemporary literature, fictionality, selffashioning, mediatization, Weihui, globalisation

I Kina spiser de hunde. De tvangssteriliserer kvinder, der ikke efterlever etbarnspolitikken, de arbejder langt flittigere end vesterlændingene og opnår snart det økonomiske verdensherredømme. Det ved enhver almindeligt informeret dansker fra spillefilm, dokumentarudsendelser, og avisernes forsider og finanssektioner. Sådan er det bare ikke i Shanghai Baby, kinesiske Zhou Weihuis internationale bestsellerroman fra I999. Her handler det om vestlige kulturprodukter, ungdommens modernitetserfaringer i Shanghais sydende storbyliv og mest af alt om fortælleren selv; hendes følelser, forfatterdrømme og seksuelle sidespring. Romanen er for længst filmatiseret og kanoniseret i standardværker om kinesisk litteraturhistorie, men mestendels i afsnit om masselitteratur eller chick lit som et sociologisk vidnesbyrd om unge kvinders drømme og langtfra som et æstetisk interessant værk (jf. Rosenmeier 2009). Weihuis sentimentale selvudlevering og sampling af vestlige citater 
og kulturfragmenter har med få undtagelser ført til den smagsdom, at Shanghai Baby er saftig chick lit (i New Statesman anmeldt under overskriften "Bridget Jones with blow jobs" (Cowley)), og Weihui en kitschet medie-darling og occidentalist, uden reelt indhold at skrive om og ganske uden klædelig selvironi, der kan gøre romanens selvbiografiske og selvfikserede passager udholdelige. ${ }^{\mathrm{I}}$

I denne artikel vil jeg imidlertid genlæse Shanghai Baby i lyset af de seneste IO-I5 års genopblomstring af det, der bredt betegnes litterær selvfremstilling, og som i sin aktuelle udformning tegnes af multi- og massemediebårne forfatterskaber spændende fra franske Michel Houellebecqs over danske (Claus Beck-)Nielsens nu nedlagte kunstfabrik Das Beckwerk og frem til det, der kunne ligne tendensens foreløbige kulmination med norske Karl Ove Knausgårds Min Kamp I-6 (2009-20II). Ved at læse den i kulturel henseende hybride roman Shanghai Baby, der tager afsæt $i$ en globaliseret kinesisk virkelighed, ind i selvfremstillingsbølgen som set fra et vestligt perspektiv, ønsker jeg at demonstrere visse globale ligheder i måden at fiktionalisere samtiden på, ligesom jeg ønsker at skærpe blikket for den mediemæssige og kulturelle kontekst, som disse fiktionaliseringer og litterære betydningsdannelser skabes i (Jenkins). Den aktuelle strømning af selvfremstillende litteratur udmærker sig blandt andet ved, at forfatterne i højere grad end tidligere forholder sig til litteraturen som ét medie blandt andre i en tæt sammenvævet kultur- og medieøkologi. Det er et træk, der udspringer af globaliseringens og medialiseringens accelerering (Hjarvard; Kjerkegaard), og som knytter sig til andre af I99o'ernes og 200o'ernes kulturelle strømninger såsom nyrealismen og virkelighedshungeren (Knudsen). Fælles for disse tendenser er, at deres brug af fiktion sigter mod at nå en større grad af autenticitet i en hypermedialiseret verden. Men den selvfremstillende litteratur rejser også spørgsmålet om, hvorvidt romanerne blot genererer forfatterstjerner til massemediernes kendiskultur (Moran) og forlænger det senkapitalistiske samfunds identitetsproduktion ind i litteraturen (Vassenden)?

Shanghai Baby fremstår umiddelbart som et skræmmeeksempel på dette: Forfatteren praktiserer en vis dullestil i medierne, hvor hun har ligget i cat fight med en tilsvarende kvindelig forfatter, Mian Mian, der mindeværdigt har beskyldt Weihui for at onanere, mens hun skriver. Weihui selv har gjort sit bedste for at drage fordel af tilsviningen og optræder på sine bogturneer som fransk femme fatale i gennemsigtige sorte blonder i stil med sin romanheltinde, mens hun sender fingerkys til fansene med den ene hånd og ryger med den anden (Kong IIO). Om dette er en iscenesættelse eller 'fiktionalisering' (et begreb jeg vender tilbage til) af forfatteren uden for værket er umuligt at afgøre, men det har uden tvivl skabt en forestilling om, at romanens forfatter og dens selvfede jegfortæller går restløst op i hinanden.

I Uden for vestlige finkulturelle kredse findes der hårdere domme for at skrive for populært: Weihuis roman blev bandlyst af KKP ved udgivelsen med den begrundelse, at Weihui er "dekadent" og "slave af vestlige værdier" (Gade). Den statsautoriserede censur er selvsagt ekstremt kontraproduktiv i internettets anarkistiske tidsalder, så Shanghai Baby formodes nu solgt i millionvis af piratkopier, den er oversat til mindst 20 sprog og har afstedkommet en mængde imitationer, først og fremmest i romanform, men også i form af selvudkrængende og seksuelt bekendende blogs (Rosenmeier 44). 
Weihuis ansigt pryder da også romanens forside på flere udgaver, og det har uden tvivl været medskabende for den læserkult, der opstod om værket i Kina (alle ville have sex på det natklubstoilet i Shanghai, hvor fortælleren har det). Ved udgivelsen af den danske oversættelse i 2002 fremhævede Anne Wedell-Wedellsborg ligefrem denne selviscenesættelse som en hovedårsag til interessen for Shanghai Baby overhovedet. I anmeldelsen "Kinesisk kioskbasker" konkluderer hun, at selvom Weihui udviser et vist skrivetalent, så er hun først og fremmest "dygtig til at efterligne international skrivestil" og repræsenterer "på ingen måde hverken avantgarden eller det specielt litterært originale i den kinesiske samtidsprosa” (6). Det er formentlig rigtigt, men som Stefan Kjerkegaard påpeger i oversigtsartiklen "Forfatter, fiktionalisering og den nye modtagerkultur" (2OII), så er det samtidig nødvendigt at holde sig for øje, at skræmmeeksempler ofte er resultatet af en reception, der, stillet over for en litteratur, der udfordrer grænserne mellem fakta og fiktion og mellem trykt bog og massemedier, giver sig til at:

"løbe efter og lade sig styre af det performative kredsløb, der ofte bevidst udspiller sig imellem, og mere fundamentalt udspiller læsere og forfattere [...] Man skal derfor passe på med ikke at læse bøgerne, fx fortabe sig i bogomslag, forfatterbiografi og til sidst det rene Se og Hør, men generelt læse det udtryk, der rummer den højeste form for kompleksitet og udfordring, og det er for litteraturens vedkommende ofte teksterne selv." (Kjerkegaard 284-285)

Den fiktionaliserede fremstilling af selvet kan godt samtidig være både 'mediestunt' og en refleksion over den tid og det samfund, jeget er rundet af. Det er min tese, at fiktionaliseringen i det litterære selvportræt fungerer som en bestræbelse på at komme nærmere en faktisk skildring af livet i globaliseringens tidsalder, men at blikket for denne form for selvrefleksion mistes, hvis man læser forfatter og fiktivt selv sammen til én instans uden blik for den merbevidsthed, som medieringen afstedkommer. I det konkrete tilfælde ville det være en decideret fejllæsning, idet Shanghai Babys fortæller rent faktisk præsenterer sig i romanens første sætning som "Ni Ke - men alle mine venner kalder mig Coco" (5) og altså ikke som Weihui. Ikke desto mindre har receptionen i vidt omfang læst forfatter og fortæller så afgjort sammen, at blandt andre Wedell-Wedellsborg eksempelvis skriver i sin anmeldelse, at "forfatterinden har været på præcis den verdensturné, bun håber på i slutningen af romanen" (6, min kursivering). Det er retrospektivt sandt, eftersom fortællingen om Coco har banet vejen for faktisk berømmelse for Weihui, men tekstanalytisk anskuet er det mere produktivt at opretholde dén skelnen, forfatteren har indskrevet $\mathrm{i}$ teksten.

Men på samme måde som hos eksempelvis Houellebecq skaber Weihuis selvfremstilling altså både en fortolkningsramme for værket og en uklarhed omkring det. De selvfremstillende romaner blander selvbiografi med fiktion på måder, der gør, at romanerne hverken kan læses meningsfuldt som fuldtonet fiktion eller som deciderede selvbiografier, hvor den referentielle basis kan afprøves faktuelt. 
Dét placerer os som læsere i en udfordrende situation, hvor vi under læsningen konstant må genforhandle forholdet mellem fiktion og fakta, så de to størrelser hverken optræder som uforeneligt modsætningspar - de spiller sammen i litteraturen - eller smelter sammen som lige gyldige størrelser, hvorved en stor del af den litterære betydningsdannelse ville gå tabt (Kjerkegaard og Munk).

\section{Coco: Et porøst subjekt i symbiose med Shanghai}

Lad os nu se nærmere på, hvordan Weihui arbejder med forholdet mellem fiktion og fakta. Shanghai Baby ligner af omfang og opsætning en gængs fiktionsroman: Fortællingen er inddelt i 32 kapitler, alle med bastant betydende titler, såsom "Mødet med min elskede" (5) eller "En moderne storby" (II), og til slut er der tilføjet et efterord samt to faktuelt anlagte notater om, at gennemskrivninger af bogens tekst er afsluttet henholdsvis 20. juni og 15 . juli I999. ${ }^{2}$ Men i efterordet (omhyggeligt dateret til 20. juli 1999) bekræftes den opmærksomme læsers snigende fornemmelse af, at romanen er "halvt selvbiografisk" (243) som det hedder, hvilket umiddelbart understøttes af efterordets sprogtone og stil, der er identisk med romanens, og af de offentligt tilgængelige informationer, der eksisterer om Weihui (f.eks. har 'de' samme alder og er 'begge' uddannede i Sprog og Litteratur på Fudan Universitet, ligesom beskrivelserne af Cocos udseende (32) harmonerer med forsideportrættet af forfatteren). Alligevel fastholdes det i samme bevægelse, at der ned til petitessen er konkrete forskelle på forfatteren til efterordet og jegfortælleren i bogens øvrige tekst. Hvor jegfortælleren Coco bedyrer, at hun hverken kan eller vil skrive på computer (26), fortæller forfatterstemmen i efterordet, at da hun havde "tastet det sidste tegn ind på computeren” (243), modtog hun et oversøisk opkald. 3 Forskellen på fortælleren Coco og efterordets forfatter overskrides nu straks igen, for efterordets prosaiske tone slår om i en af de meget poetiserede billeddannende sekvenser, som Coco bruger i de skønlitterære afsnit, hver gang hendes tyske elsker Mark træder ind på scenen:

Sollyset uden for vinduet var ved at blive svagere, vedbenden kravlede op omkring balkonerne på de gamle udenlandske bygninger i fransk stil, og barnet ovenpå øvede sig på at spille ”Für Elise” på klaver. Jeg skoddede min cigaret i askebægeret og sagde på tysk ind i røret: ”Jeg elsker dig”. (243)

2 Jeg benytter førsteudgaven af Rosinantes danske oversættelse fra 2002, der er oversat fra kinesisk af Christian Svendsen og rost af danske kinesisk-kyndige (Wedell-Wedellsborg 6). Citering fra værket sker med henvisning til sidetal i en efterstillet parentes.

3 Man kan strengt taget ikke vide, om efterordets forfatter er kvinde eller mand, faktisk person eller endnu en romankarakter, men jeg læser denne som kvinde, idet hele romanens raison d'être er spillet på forfatteridentiteten og i forlængelse af Susan Lansers teori fra The "I" of the beholder (2005) om, at tekster inviterer til en vis identifikation mellem forfatter og hovedperson i de tilfælde, hvor der er anonymitet på øverste diegetiske niveau (2I2). 
Er det Mark, der ringer, eller er det en helt anden fra virkelighedens verden? For den plotbegærlige læser, der over mere end 200 sider har fulgt Cocos uafklarede kærlighedsforhold til tyskeren, er det snart sagt umuligt ikke at læse den ellers stærkt fiktionsmærkede stereotyp ind i den anden ende af røret $\mathrm{i}$ en forløsning, der lader fortælling og efterord, Coco og Weihui - kort sagt fiktion og fakta - smelte afgjort uafgørligt sammen. ${ }^{4}$ Hvordan forholder man sig som læser til dette?

I The Rhetoric of Fictionality (2007) redegør Richard Walsh for, hvordan værker kan signalere, at indholdet er fiktionaliseret, eller 'fiktionalitet', for at bruge Walshs præcise begrebsliggørelse, og derfor ikke skal læses referentielt. Teksten kan ligeledes signalere overensstemmelse med virkeligheden og således invitere til referentielle læsninger. Den samtidige sammensmeltning og demonstrative udpegning af forskelle forfatteren og fortælleren imellem sender imidlertid dobbelttydige invitationer til læseren af Shanghai Baby. Nogle begivenheder og karaktertræk i romanen vil således invitere til at opfatte værket som fiktivt, mens andre vil pege på det biografiske. Derudover er der med Louise Brix Jacobsens formulering en tredje tilstand af "svævende referentialitet"; en uklar referentialitet, der fastholder læseren $i$ en tøven og fordrer et hyperbevidst fortolkningsarbejde i konstant forhandling mellem fiktion og fakta og mellem værk og kontekst (Jacobsen 62).

Walshs teori er i Danmark især blevet udbredt via Henrik Skov Nielsens udvidede anvendelse af fiktionalitetsbegrebet. Mens fiktion som bekendt betegner en genre eller kategori, betegner begrebet fiktionalitet en egenskab ved et givet værk eller et stykke kommunikation: nemlig en strategisk bearbejdning af stoffet, der er udtryk for intentionalitet. Ifølge Skov Nielsen er fiktionalisering en retorisk strategi, der benyttes i alle former for kommunikation, herunder den litterære. At noget opfattes som fiktionaliseret medfører, at det tilskrives intentionalitet. Med Nielsens spidsformulering: "Fiktionalisering er en handling, hvormed man gør noget med virkeligheden og med vilje og med et formål" (Nielsen 7).

Opfattelsen af fiktionalisering som et greb, der netop skal forstås som led i en seriøs verdensvendt diskurs, er givende for læsningen af Shanghai Baby. Den 'svævende referentialitet' kan læses som en bestræbelse på at etablere et fortolknings- og erkendelsesrum mellem selv og kontekst, fortid og nutid. I en delvis biografisk, delvist fiktiv fortælling som Shanghai Baby betyder fiktionaliseringen derfor, at individets erfaringer kalder på at blive læst som en form for samtidshistorie, idet der fortælles fra det enkelte menneskes synspunkt - midt $\mathrm{i}$ begivenhederne.

Coco bor og arbejder i Shanghai i slutningen af I990'erne, hvor byfornyelserne og tilflytningen er på sit højeste. Hun er inspireret af Margurite Duras, der ligger næsten øverst på hendes "liste over idoler, mens nummer et naturligvis er Henry Miller" (5). Dette "naturligvis" uddybes ikke, men giver sig til kende i den til tider surrealistiske, stream-of-consciousness-agtige og vildt idiosynkratiske stil, hvormed det porøse og altid begærlige subjekt Coco beretter om sine erotiske eventyr 
i ambivalent symbiose med byen Shanghai, der determinerer alt fra hendes valg af mænd til hendes beslutning om at blive forfatter; hun har godt nok en ublu drøm om at løsrive sig fra byen til fordel for et liv som berømthed på verdensscenen, men selv dette er betinget af byen:

Det [at ville være berømt] har meget at gøre med at jeg bor i Shanghai. Byen er indhyllet i askegrå smogtåger og tynget af rygter, men også præget af arrogance, et levn fra tiden med de gamle udenlandske koncessionsområder. Denne arrogante stemning pirrer en følsom og stolt pige som mig - derfor både elsker og hader jeg den. (5)

Coco fremstilles som et produkt af historiske vektorer, idet hendes personlige splittelse spejler Shanghais komplicerede position i den kinesiske historie og kollektive bevidsthed. På grund af den semikolonialisering, koncessionsområderne udgjorde, opfattes den store havneby af mange kinesere som "a constant reminder of a history of national humiliation" (Lee XI), ligesom den luksuriøse storby-livsstil, som de rige handelsmænd bragte med sig til bondelandet, fik byen udnævnt til "a bastion of decadence and evil" (ibid.: XI). ${ }^{5}$

På den anden side nød venstre-intellektuelle kinesere godt af byens moderne bekvemmeligheder, ligesom de følte sig distancerede fra deres landsmænd i rismarkerne. Selvom de ikke havde megen personlig kontakt med vesterlændingene, var deres livsstil i mange henseender ganske vestlig, hvilket gav anledning til samvittighedsnag i forhold til nationen (ibid.: 309), på samme måde som Coco konstant har det $\mathrm{i}$ forhold til sin impotente kinesiske kæreste Tiantian. Hun bedrager ham med handelsmanden Mark, der fremstilles som en neoimperialistisk genganger fra fortiden, der på næsten sadomasochistisk vis betvinger og tilfredsstiller Coco. Et trekantsdrama, der fungerer som allegori over den kinesiske magtesløshed over for den vestlige kultur og kapitalismes forbrugsgoder.

På grund af den nydelsesfulde medskyld i egen fornedrelse beskriver Coco Shanghai som "denne letsindige, forlystelsessyge by" (26) fyldt med "vulgære, sentimentale og mystiske følelser" (26). Ikke helt koloniseret, men snarere hybridiseret bliver Shanghai "enestående i Østen. Her er Kina og Vesten smeltet sammen siden 3o'erne og har udviklet en fælles kultur. Og nu ruller den anden bølge af vestlig indflydelse ind over byen" (26). Coco beslutter sig derfor for at skrive en fin de siècle-agtig roman om Shanghai i slutningen af det 20. århundrede, men portrættet bliver i lige så høj en palimpsest, hvor I920'ernes og 30'ernes aftryk stadig er synlige gennem nutidens moderne lag af storby.

Ved hjælp af Weihuis fiktionalisering af byen bliver det klart, at de strukturer, som er blevet etableret under først semikolonialismen, så kulturrevolutionen og nu under "den anden bølge af vestlig indflydelse", alle stadig er virksomme: Shanghai

5 Et image som KKP fastholdt og udnyttede i deres mobilisering og idealisering af det jævne uspolerede bondesamfunds kamp mod de fordærvede storbyelitister (ibid. XII). 
udgør på denne måde et hyperkomplekst rum, hvis anakronistiske blanding af moderne skyskrabere, fransk empirestil og gammeldags kinesiske pagoder får tiden til at fremstå ikkelineær, men snarere ordnet i forskellige synkrone tidsligheder. Som konglomerater af denne ikkelineraritet kan Coco og byens øvrige indbyggere da heller ikke finde rundt, men ender ofte med at fare vild:

Jeg blev svimmel af, at taxaen kørte i ring. Chaufføren var helt ny i jobbet, havde kun et par dages erfaring og var så forvirret, at han kørte os tilbage til vores udgangspunkt. Selv er jeg fuldstændig uden retningssans og kunne kun sidde og råbe og skrige. (68)

Coco har mistet retningssansen og bliver i løbet af fortællingen stadig mere rodløs og deprimeret. Men samtidig arbejdes der via fiktionaliseringen på en form for genvinding af retningen ved hjælp af fortællingen om livet i Shanghai, der kan fungere som en løselig kortlægning af tiden og rummet. Denne kortlægning er en slags erindringsarbejde, der ifølge Andreas Huyssen er nødvendig for individets fodfæste: "memory discourses are absolutely essential to imagine future and to regain a strong temporal and spatial grounding of life and the imagination in a media and consumer society that increasingly voids temporality and collapses space" (Huyssen 3). ${ }^{6}$ At den mentale og sociokulturelle kortlægning sker litterært, giver mening på flere niveauer, idet Shanghai fra 1920 og små ti år frem var centrum for en litterær revolution, hvor kinesiske forfattere tilegnede sig den moderne europæiske litteraturhistorie. Særligt romantik, realisme og symbolisme var populære stilarter blandt unge forfattere, fordi de var let forenelige med kinesiske traditioner, men også naturalisme, ekspressionisme, dada og surrealisme blev approprieret gennem oversættelse, kritik, efterligning og tilpasning. Det skabte grobund for kulturel fornyelse, indtil Chang Kaishek indledte sin undertrykkelse med Shanghai-massakren i 1927, hvorefter litteraturen i lang tid befandt sig i et dødvande (Hertel m.fl. 427).

\section{Kliché, kitsch og vits: Weihuis anstødelige stil}

Der er altså historisk og æstetisk ræson i, at Coco griber tilbage til denne guldalder og stjæler med arme og ben fra særligt den europæiske modernisme. Måden, hvorpå der krydshenvises, lægger dog ikke op til nærlæsning eller detaileksegetiske analyser, sådan som man ofte behandler modernistiske hovedværker - snarere tværtimod.

6 Marie Hastrup giver et slående eksempel på, hvordan moderniseringens radikale ændringer af kulturen ses i nye sproglige tvetydigheder: Ordet guangchang, der betyder 'stor plads' og hidtil har refereret til politiske pladser (f.eks hedder den Himmelske Freds Plads 'Tiananmen guangchang' på kinesisk), erstatter i dag gamle udtryk for 'indkøbscenter', idet navnet bliver givet til byernes nye kommercielle centre og pladser. 'To give the name guangchang to a plaze - a commercial business center - is a political transgression, signifying to the country the gradual transformation from the socialist path to the capitalist market economy" (Dai 3I citeret i Hastrup 44). 
Hvert kapitel indledes af op til tre, oversatte såvel som uoversatte, citater af vestlige filosoffer, forfattere og (i overensstemmelse med den nyfeministiske Cocos ambitioner) kendte kvinder generelt. Citaterne eller mottoerne fungerer i høj grad som en slags overeksponering af de multimediale diskurser, der udgør det modernes fælleshistoriske underbevidsthed. Kapitel 3 hedder således ”Jeg har en drøm” og indledes med følgende citat: "And the good girls go to Heaven, but the bad girls go everywhere." Efterfulgt af: "En kvinde, der vælger at blive forfatter, gør det ofte for at få en position i det mandsdominerede samfund.” Det er umuligt at afgøre, om det første Jim Steinman-citat fremhæver banaliteten i Cocos identifikation med 'den slemme pige' eller rationalet bag den, og på samme måde både udlægger og udhænger det andet Erica Jong-citat Cocos forestillinger om muligheder for social opstigning. Men citaterne er genkendelige som en slags samfundsstemmer fra reklame-billboards, internetsurfing osv. og fremstår med deres mængde og i en romanform ikke længere naturaliserede, men skingert højlydte. Som Rune Lykkeberg påpeger i "Samtidsdiagnose og litteraturlæsning" (2009), så er forudsætningen for, at vi genkender et værk som samtidslitteratur, at vi allerede har en klar opfattelse af, hvad der konstituerer samtiden. Denne opfattelse udgøres ofte af brokker fra de politiske diskurser og af mediernes modeord, nyhedsvinklinger og dramaserier med aktuelt tilsnit. Tilværelsen går imidlertid ikke restløst op i disse diskurser, så hvis samtidsromanen skal fungere som mere end et talerør for denne afpersonaliserede samtidsstemme, så må vi som læsere selv gøre litteraturen til genstand for erkendelser af det samtidshistorisk relevante. Som Lykkeberg normativt udtrykker det i en omskrivning af Herbert Marcuse: "Samtidsromanen udfordrer samtidens monopol på at definere, hvad der er samtiden" (Lykkeberg I28).

Set fra et historiografisk synspunkt, kan man sige, at de modsatrettede viljer til henholdsvis kortlægning og kaos skaber en form for samtidshistorieskrivning, der kombinerer to hensyn: På den ene side arbejder Weihui via plotningen af en romanfortælling frem mod en linearitet i form af et sammenhængende narrativ, der tilskriver mening til de tilfældige hændelser, der udgør vores liv og samtid. Hayden White fremhæver i The Content of the Form (I987) den narrative tendens i al historieskrivning som ideel til at skildre menneskers handlinger, idet vi ikke blot efterlods organiserer betydning gennem fortælling, men allerede imiterer fiktionens mønstre, når vi handler. I den absolut modsatte ende af det metahistoriske spekter argumenterer Michel Foucault til gengæld for en spatial historieskrivning, der i forlængelse af filosoffen Nietzsches genealogi prioriterer detaljen over helheden for at give et ikke-reduktivt billede af de mange delelementer, der konstituerer en begivenhed eller betydning.7 Weihui prioriterer gennem hele romanen den spatialt orienterede historieskrivning i form af kuriøse visuelle detaljer og slående enkeltscener over plot og syntese.

Samtidshistorieskrivningen er generelt udspændt mellem på den ene side at

7 Jeg støtter mig i denne udlægning af forholdet mellem Foucaults og Whites historiesyn til Tore Rye Andersens redegørelse for 'den neohistoriske roman' (Andersen 1999). 
være genkendelig som sådan og på den anden side at være i fare for blot at mime en anonym samfundsstemme med klichéfyldte synspunkter og karakterer til følge. Weihuis fiktionalisering af samtiden og sig selv fører i første omgang ikke til, at hun træder i karakter, men snarere til, at hun træder "ind i klichéerne", som det hedder med en formulering fra Lykkeberg (I26). Det fremmeste eksempel på en sådan kliché i Shanghai Baby er den tyske Mark med de "Donaublå øjne” (30). Han taler engelsk med "kraftig tysk accent" (30), som man kender det fra fremstillinger af nazister i amerikanske populærfilm, og så har han et meget stort (og meget omtalt) lem, et træk, man ligeledes genkender fra kulturprodukternes nazistbeskrivelser. ${ }^{8}$ Coco erkender blankt, at hun "faldt for hans faste balder og nazistiske knoglebygning” (I22). Nazi-anakronismen Mark etablerer således et fortolkningsrum mellem I930'erne og I990'erne, som her i en af romanens berømte samlejescener mellem Mark og Coco:

Han holdt mig op mod den lilla væg, løftede min kjole, fik behændigt mine Calvin Klein-trusser af, rullede dem sammen og stak dem i baglommen. Så løftede han mig med utrolig kraft og trængte præcist ind. Jeg mærkede intet andet, end at jeg sad på hans pik som på en glohed og farlig brandhane. (70)

Shanghai Baby er blevet solgt som pornografi eller 'erotik' (som der er stemplet på mit eksemplar fra Aarhus Kommunes Hovedbibliotek). Men den koreograferede seksualitet, som fremstilles her, kommer i højere grad fra den stiliserede reklameverden. Billedet af den sort-hvide Coco (hun er bleg og sorthåret) overskrævs på en stor rød brandhane mod en ensfarvet baggrund, er som taget ud af en af Calvin Kleins meget ikonografiske reklamer. Mark inkarnerer på parodisk vis den sadomasochistiske tiltrækning af nazismens brutalitet, men også af det kropsæstetiske ideal, man kender fra fascismen, og som ifølge Susan Sontag gennemsyrer de moderne kapitalistiske samfunds skønhedskult, mens æstetikkens politiske og etiske implikationer går i glemmebogen (jf. Sontag I975).

\section{Kina spiser de hunde og skriver global samtidslitteratur}

Wedell-Wedellsborg efterlyser i sin anmeldelse en "selvironi og underfundighed, som kunne have løftet bogen ud over det kitschede" (6). En tydelig ironi ville måske også bringe pointer som ovenstående mere utvetydigt frem i fortællingen. Men spørgsmålet er, om ikke der er en slags merbevidsthed til stede, for der praktiseres en form for deadpan humor på Cocos bekostning. Eksempelvis modsvares de heftige sexscener mellem Coco og hendes neoimperialistiske elsker af en lakonisk oplysning om, at den impotente kinesiske kæreste spiller det vestlige computerspil

8 Eksempelvis i Julia Francks roman Die Mittagsfrau (2007) og i provo-bandet Rammsteins pornofilmsinspirerede musikvideo Pussy fra 2009, hvor forsangeren, Till Lindemann, synger på en blanding af tysk og engelsk og overidentificerer sig med nazi-stereotypen. 
The Empire Strikes Back. Spillet henter selvsagt sin titel fra Star Wars-filmene, men med bevidstheden om Shanghai som tidligere centrum for et vestligt finansimperium in mente får spillet karakter af både at resignere og ironisere over for de unge kineseres ringe modstandsdygtighed i forhold til den vestlige kultur. Vigtigere endnu er det, at der i romanen demonstreres en historisk bevidsthed, som rækker ud over Cocos occidentalistiske tilbedelse af Vesten. Det nævnes ikke eksplicit af Coco, at Europa er blevet kompromitteret af nazismen siden den første "bølge af vestlig indflydelse" rullede ind over Shanghai, men forglemmelsen af det (eller ligegyldigheden over for det) markeres subtilt, idet jegfortælleren kalder sig Coco efter det franske modeikon Coco Chanel, der 'også' havde en nazistisk elsker (Hans Günther von Dincklage, tysk officer og nazistisk spion). Efter Anden Verdenskrig var Chanel derfor i miskredit hos franskmændene og flyttede til Schweiz, men er i dag, i det der ligner en tidsalder af glemsel (jf. Huyssen 7), rehabiliteret i talrige heroiserende film og musicals som utvetydigt ikon for kvinders økonomiske og seksuelle emancipation. ${ }^{9}$ Glemslen er i udgangspunktet Vestens egen, men fremføres f.eks. i Danmark som et eksempel på asiatisk uvidenhed i tendensartikler om tøjbutikker i Asien, der dyrker den nazistiske æstetik og ikonografi uden bevidsthed om folkemord og diktatur (Heeger). På den måde er Shanghai Baby samlet set mere subtil, end fortællerfiguren alene, og det chick lit-agtigt selvsmagende og klichéfulde er forlenet med en intentionalitet $\mathrm{i}$ lighed med den, man finder inden for pop-art: Hvor Coco på den ene side er historie- og holdningsløs, så annammer, imiterer, genskaber og forvrænger Weihui den moderne tilværelses kompleksitet med blik for både etiske dilemmaer i forhold til glemslen af egne traditioner og den vestlige indflydelse på kinesisk kultur og egen medskyld deri; en medskyld, forfatteren tager på sig i kraft af sin selvbiografiske tilknytning til Coco. Fiktionaliseringen udstiller således både forfatterselvet som produkt af historiske vektorer, og viser det som en meddelagtig agent i samtiden.

Flerdelingen af fortællerinstansen bidrager desuden til at anskueliggøre forskellige niveauer i afsenderpositionen: den opleves som stærkt verdensvendt på grund af det selvbiografiske islæt, men Shanghai Baby benytter sig samtidig af fiktionens mulighed for overskridelse af selvet og for at have flere blikke på verden samtidigt. At skrive om sig selv er desuden selvfremstilling både i betydningen selvfremvisende og selvproducerende. Men det paradoksale ved selvskrivningen er, at det tekstligt producerede selv aldrig kan identificeres endeligt med den skrivende. Som Arne Melberg formulerer det, så indebærer selvskrivning uundgåeligt, at "jeg'et fordobles til en instans, som omskriver og reflekterer over det jeg, som lever og har levet" (Melberg 195).

Man kunne indvende, at det æstetisk interessante ved Shanghai Baby i højere grad fremkommer ved hjælp af de kulturelle og litterære perspektiver, romanen

9 Herunder de nyere film Coco avant Chanel (2009), der kun beretter om Chanels livshistorie frem til Første Verdenskrig eller Coco Chanel \& I Igor Stravinsky (2009), der fokuserer på hendes affære med den russiske komponist Stravinsky. 
kan tilskrives, end i kraft af dens tekst alene, og det har da her heller ikke været mit ærinde at vurdere, om Shanghai Baby samlet set er 'en god bog' (der er snarere tale om 'en mærkelig bog'). Imidlertid er det en vigtig pointe, at den illustrerer, hvordan fiktionsromanen af $i$ dag interagerer med konteksten i et kulturelt, globalt og multimedialt samspil, der ikke kan eller bør udelukkes, hvis vi skal forstå samtidslitteraturen. Som en hybrid mellem vestlige og kinesiske stilarter kan Weihuis roman siges at være endt i samme position på den litterære verdensscene, som en stor del af den globale samtidskunst, som Boris Groys beskriver metaforisk som en asylant i Tyskland:

En tyrker i Tyrkiet eller en kineser i Kina virker malerisk, autentisk og tiltrækkende [...]. Men en asylant er ikke udpræget romantisk. Han er ikke længere en autentisk tyrker eller kineser, fordi han gennem sit ophold i Tyskland i kulturel henseende har bevæget sig væk fra sit eget land. Man siger om asylanten, at han forsøger at efterligne det tyske, at tilpasse sig den herskende kulturelle norm. Men ifølge enhver romantiker er tilpasningen til den kulturelle norm en utilgivelig forbrydelse mod autenticiteten og den kulturelle originalitets hævngerrige guddom. Intet kan forarge en romantiker mere end at afsløre det fremmede som en dårlig parodi på det kendte. (Groys 59)

Ifølge Groys findes der en stor gruppering af samtidskunst, der regnes for æstetisk skuffende i dobbelt forstand, idet den hverken formår at formidle et 'traditionelt' autentisk vidnesbyrd om fortid og samtid ('kineseren i Kina') eller, som avantgarden, at formulere radikale opgør med fortid og nutid, der peger ind i fremtiden. Denne samtidskunst fra omkring årtusindskiftet afspejler en globaliseret samtid, der måske for første gang i verdenshistorien ikke forventer sig noget revolutionerende nyt af fremtiden, og derfor i stedet opholder sig ved den aktuelt foreliggende verden. Den er slet og ret blevet samtidig, med alt hvad det indebærer af ufærdig refleksion og repræsentation (ibid.: 60). Shanghai Baby eksemplificerer dette som en hybrid af genrer og stilarter såsom selvbiografi, klumme, Harlequin-kioskbasker, pop-art, chick lit, storbyroman og erindringsfortælling, og fiktionaliseringen af stoffet etablerer et refleksionsrum mellem fortid og nutid. Romanen nedbryder desuden barrierer mellem høj- og lavkultur, mellem trykt litteratur og internet og mellem Kina og Vesten - ikke i form af den kontemplative nydelse, den traditionelle roman bibringer, men snarere performativt i kraft af en ufravendt og direkte henvendelse, der sampler fra så mange forskellige genrer, lag og diskurser, at den rækker ud over romanens grænser. 


\section{LITTERATURLISTE}

Andersen, Frits. "Verdenskunst, antropoetisk prosa og transnational kolonialismekritik". Hvad er verdenskunst? Red. Baggesgaard, Mads Anders, Ida Krøgholt og Lotte Philipsen. Århus: Klim, 2009, 67-86.

Andersen, Tore Rye. "Mason \& Dixon og I70o-tallet". I70o-tallets litterare kultur. Red. Andersen, Frits, Per Dahl og Ole Birklund Andersen. Århus: Aarhus Universitetsforlag, 1999, I74-202.

Cowley, Jason. "Bridget Jones with blow jobs". New Statesman 23. juli 200I. http://www.newstatesman. com/node/140835

Gade, Solveig. "Kinas nye kvinder". Jyllands-Posten I3. juni 2002, II

Groys, Boris. ”Asylanten i æstetisk perspektiv". Lettre Internationale nr. I, september 2003, 59-60.

Hastrup, Marie. Kinas slemme drenge og frakke piger. Upubliceret speciale. Afdeling for litteraturhistorie, Aarhus Universitet, 1999.

Heeger, Troels. "I Asien hitter Hitler". Dagbladet Information 3. oktober 2012. http://www.information. $\underline{\mathrm{dk} / 3 \mathrm{I} 2763}$

Hertel, Hans. Red. Verdens Litteraturhistorie, bind 6. København: Gyldendal, 1995.

Hjarvard, Stig. En verden af medier. København, Samfundslitteratur, 2008.

Huyssen, Andreas. Twilight Memories. New York: Routledge, 1995.

Huyssen, Andreas. Present Pasts: Urban Palimpsest and the Politics of Memory. Stanford: Stanford University Press, 2003.

Jacobsen, Louise Brix. "Fiktiobiografisme. Perception og fiktionalisering". Spring 3I/32 (20II): 57-78.

Jenkins, Henry. Convergence Culture. New York: New York University Press, 2006.

Kjerkegaard, Stefan. "Forfatter, fiktionalisering og den nye modtagerkultur". Spring 3I/32 (20II): 260-293.

Kjerkegaard, Stefan \& Anne Munk Myrup. ”Litterær selvfremstilling og autofiktion i en skandinavisk optik". Millennium. Nye retninger i nordisk litteratur. Red. Mads Bunch. København, Spring. 2013. 325-348.

Knight, Sabrina. "Shanghai Cosmopolitan: class, gender and cultural citizenship in Weihui's Shanghai Baby." Lu, Jie Red. China's Literary and Cultural Scenes at the Turn of the 2I.th Century. Red. Jie Lu: New York, Routledge, 2008.

Knudsen, Britta Timm. Virkelighedshunger. København: Tiderne Skifter 2003.

Kong, Shuyu. Consuming Literature - Bestsellers and the commercialization of Literary Production in Contemporary China. CA; Stanford University Press, 2005.

Lanser, Susan. "The "I" of the beholder". Blackwell Companion to Narrative Theory. Red. James Phelan and Peter Rabinowitz. Blackwell, 2005.

Lee, Leo Ou fan. Shanghai Modern. London: Cambridge University Press, I999.

Lykkeberg, Rune. "Litteraturlæsning og Samtidsdiagnose". Kritik nr. I9I (2009), I23-I3I.

Melberg, Arne. "Selvfremstillende strategier". Selvskreven - om littercer selvfremstilling. Red. Stefan Kjerkegaard. Århus: Aarhus Universitetsforlag, 2006.

Moran, Joe. Star Authors. London: Pluto Press, 2000.

Nielsen, Henrik Skov. "Fiktion, fiktionalitet og unaturlige fortællinger". Spring 3I/32 (2OII): 7-2I. Rosenmeier, Christopher. "Fra masselitteratur til masser af Litteratur". Kinabladet nr. 43a (2009). 
Sontag, Susan. "Fascinating Fascism". New York Review of Books, 6. februar 1975.

http://www.nybooks.com/articles/archives/1975/feb/o6/fascinating-fascism/?pagination=false

Vassenden, Eirik. "Hva er "samtidslitteratur" og hvorfor leser vi den?". Edda nr. 4 (2007). 357-37I.

Walsh, Richard. Rhetoric of Fictionality. Ohio: The Ohio State University, 2007.

Wedell-Wedellsborg, Anne. "Kinesisk Kioskbasker". Litteraturmagasinet Standart nr. 3, september 2002, 6 .

Weihui. Shanghai Baby. København: Rosinante, 2002. 